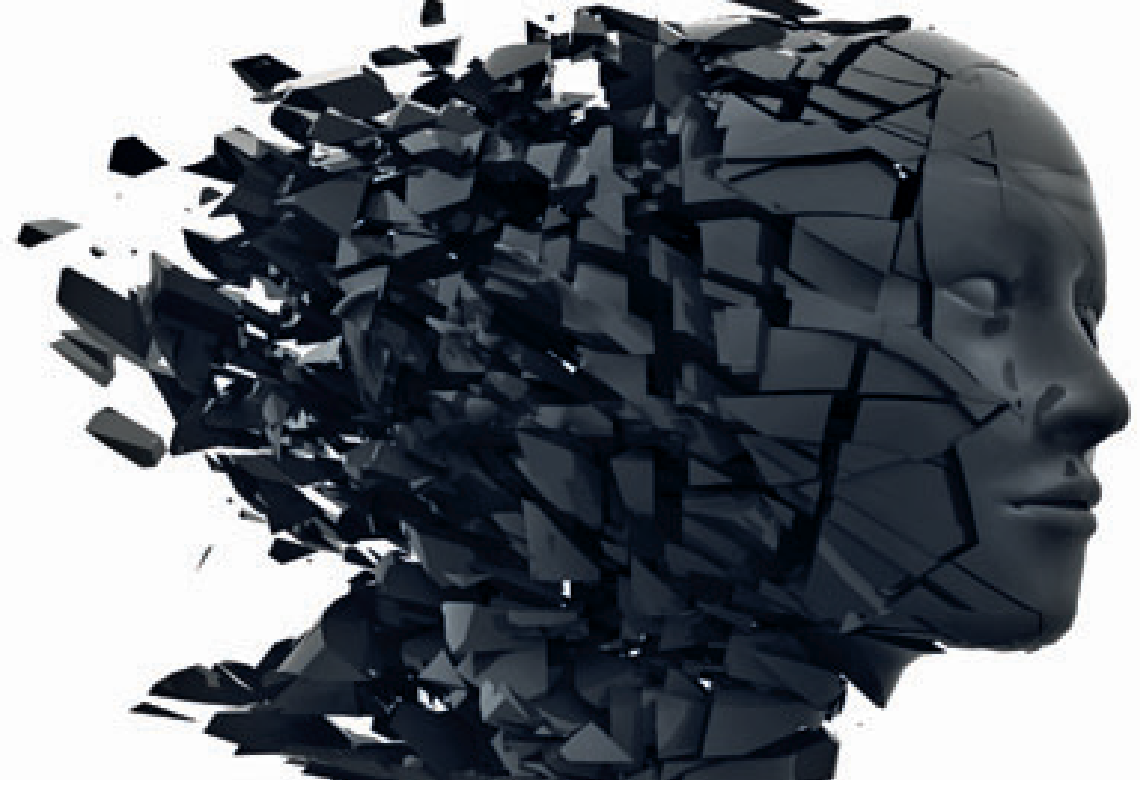

Illustrasjonsfoto Istockphoto

\title{
Quetiapin gir færre nye psykoser
}

\section{Vedlikeholdsbehandling med quetia- pin i minst ett år minsker risikoen for tilbakefall hos asymptomatiske pasienter etter første psykoseepisode.}

En studie fra Hongkong omfattet 178 personer med schizofreni eller ikke-affektive psykotiske lidelser som etter første psykoseepisode hadde fått minst ett års antipsykotisk behandling og som var uten psykosesymptomer ved studiestart (1). Pasientene ble randomisert til enten vedlikeholdsbehandling med quetiapin $400 \mathrm{mg} / \mathrm{dag}(\mathrm{n}=$ 89) eller placebo $(n=89)$ og fulgt i 12 måneder eller til residiv av psykose.

Andelen som fikk ny psykose innen 12 måneder var $41 \%$ i quetiapingruppen og $79 \%$ i placebogruppen $(\mathrm{p}<0,001)$. Til tross for at quetiapin generelt ble godt tolerert, var hyppigheten av seponering pga. bivirkninger større i quetiapingruppen enn i placebogruppen (18\% versus $8 \%$ ).
- Undersøkelsen viser at risikoen for psykoseresidiv hos førsteepisodepasienter med schizofreni uten psykotiske symptomer er svært høy det første året etter avsluttet behandling, selv etter ett års stabil antipsykotisk behandling. Det finnes ingen gode prediktorer for residiv. Pasientene bør derfor tilbys behandling av lengre varighet, etter avveining av mulige effekter og bivirkninger, sier Henrik Lublin ved Psykiatrisk Center Glostrup til Ugeskrift for Lager.

\section{Erlend Hem \\ erlend.hem@medisin.uio.no \\ Tidsskriftet}

\section{Litteratur}

1. Chen EY, Hui CL, Lam MM et al. Maintenance treatment with quetiapine versus discontinuation after one year of treatment in patients with remitted first episode psychosis: randomised controlled trial. BMJ 2010; 341: c4024.

\section{$\emptyset$ kt mortalitet ved migrene?}

Migrene med aura er forbundet med økt mortalitet, ifølge en ny populasjonsbasert kohortstudie fra Island (BMJ 2010; 341: c3966). Studien omfattet 18725 menn og kvinner født i årene 1907-35. Median oppfølgingstid var 25,9 år (0,1-40 år).

For personer med migrene med aura var det $ø$ kt risiko for $d ø d$ av alle årsaker med en hasardratio på 1,21 (95\% 1,12-1,30) i forhold til personer uten hodepine.

Problemet med studien er at migrenediagnosen er usikker, ifølge en kommentar i Ugeskrift for Læger (2010; 172: 2740). Men tidligere og bedre studier har vist at migrene med aura, men ikke migrene uten aura, er forbundet med en fordobling av risikoen for hjerneslag. P-pillebruk og røyking øker risikoen ytterligere.

\section{Memantin som behandling ved demens?}

For mennesker med mild til moderat lewylegemedemens har behandling med memantin en liten effekt på global klinisk status og atferdssymptomer, ifølge en studie med 199 pasienter fra åtte land (Lancet Neurol 2010; 9: 969-77).

Pasientene hadde mild til moderat parkinsondemens eller lewylegemedemens og ble randomisert til placebo eller memantin ( $20 \mathrm{mg} / \mathrm{dag}$ ). Ved vurdering etter 24 uker var det litt større forbedringer ved Alzheimers globale vurderingsskår og nevropsykiatrisk skår for pasienter med lewylegemedemens, men ikke ved parkinsondemens.

Det var dessverre ingen effekt ved parkinsondemens og kun beskjeden effekt ved lewylegemedemens. Det er derfor neppe grunn til å endre dagens praksis, ifølge en kommentar i Ugeskrift for Læger.

\section{Lange, korte eller ingen kompresjonsstrømper?}

\section{Risikoen for dyp venetrombose etter hjerneslag øker hvis pasienten bruker kompresjonsstrømpe som går til under kneet.}

Kompresjonsstrømper blir ofte brukt for å forebygge dyp venetrombose. Ved 112 britiske sykehus ble pasienter som var immobilisert etter hjerneslag randomisert til enten kompresjonsstrømper som rakk opp til hoften $(\mathrm{n}=1552)$ eller strømper som gikk til under kneet $(n=1$ 562) (1). Ultralydundersøkelse ble foretatt etter 7-10 dager og 15-20 dager. Proksimal dyp venetrombose ble påvist hos henholdsvis $6,3 \%$ og $8,8 \%$ i hver gruppe $(p=0,008)$.

I en tidligere studie fra samme forsknings- gruppe var det ingen forskjell i forekomsten av dyp venetrombose ved bruk av kompresjonsstrømpe opp til hoften og ingen bruk av strømper, og det var flere komplikasjoner hos dem som brukte strømper (2). Den nye studien kan derfor tyde på at bruk av kort kompresjonsstrømpe etter hjerneslag faktisk øker tromboserisikoen. Metaanalyser av flere studier støtter en slik tolking (1).

- Kompresjonsstrømper har neppe noen plass i behandlingen etter hjerneslag, sier professor Bent Indredavik ved Avdeling for hjerneslag, St. Olavs hospital. - Dette er i tråd med nye norske retningslinjer. Det er usikkert om funnene har relevans for andre pasientgrupper med økt risiko for dyp venetrombose. Jeg ser frem til resultatene fra en pågående studie fra samme forskningsgruppe om intermitterende pneumatisk kompresjon som alternativ til kompresjonsstrømper. Slike undersøkelser viser hvor viktig randomiserte studier om profylaktiske prosedyrer er for å evaluere klinisk praksis, sier Indredavik.

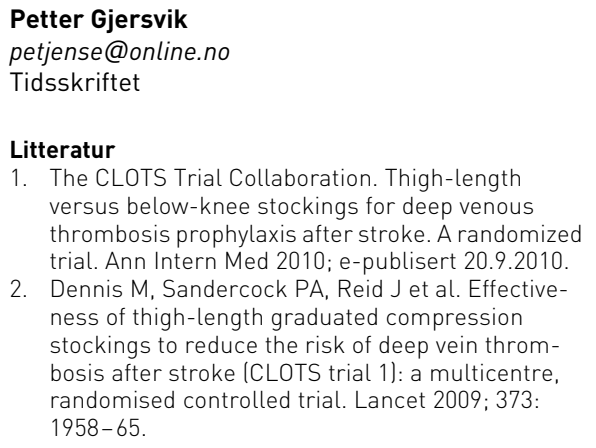

